\title{
Zakat as a Pluridimensional Concept
}

\author{
Abderrazak Belabes \\ Islamic Economics Institute, King Abdulaziz University, Jeddah, Saudi Arabia
}

\begin{abstract}
The aim of this study is to highlight the need to think zakāt as a pluridimensional concept. It cannot be studied in depth without a thought that contextualizes, connects and globalizes everything that its existence implies for actors who do not perceive it in the same way. This approach allows to face the error, illusion, uncertainty and risk that may arise from the feeling of sufficiency, which purports to exhaust the real from a specific point of view, especially that which comes from the financialism that perceives zakàt as a constituent of social finance. Hence the need for an eminently collective effort of reflection to provide everyone to refine his peculiar thought and to apprehend the phenomenon as a whole which shows the zakat, in its deepest essence beyond the legal aspect, as a means to create or maintain the social link.
\end{abstract}

Key-words: Zakat, Methodology, Pluridimensional concept, Financialism JEL Classification: B41, B55, G23, Z13

\section{INTRODUCTION}

Research on zakāt has grown considerably in recent decades as the writings show in several languages. The disciplinary compartmentalization governing academic research, however, acts as a barrier to approaching the concept as a global object involving various dimensions related to jurisprudence, economics, and finance, as well as history, anthropology, sociology, or psychology. The paradox is that despite analytical and empirical progress, there is a growing inability to think the concept in a global way.

Thinking zakāt as a pluridimensional concept allows us to confront, at the same time, the error, illusion; uncertainty and risk that can arise from the feeling of sufficiency which claims to exhaust reality from a specific point of view. This raises the need for an eminently collective effort of reflection, capable of enabling everyone to refine his singular thinking and to understand the phenomenon as a whole.

The study begins with the parable of the blind men and the elephant to better understand this problematic, where all participants refer to zakat from a particular perspective, without trying to link the knowledge of the parties concerned to that of the whole; illustrated through the distinction between the general and the specific meaning of the concept. The need to approach this as a pluridimensional object is based on the perspectives developed in finance and anthropology, even if the latter remains somewhat underestimated in view of the available literature. This leads us to consider the contemporary discourse on 
zakāt as a field of study worthy of interest for exploring the underlying implicit assumptions. The conclusion recalls the principal results and proposes some possible extensions.

\section{THE PARABLE OF THE BLIND MEN AND THE ELEPHANT}

One day, a king summoned a group of blind men. When asked if they knew about the elephant, their answer was: No. He then asked if they wished to know him and the blind men replied: Yes. Immediately, the king ordered that an elephant be brought and told them to touch it. They were questioned as to what the nature of the elephant was, and each one of the blind men likened it to a known object based on the specific forms they felt. In the end, they accused each other of being wrong before the king told them that the body of the elephant is unique; it is the divergent perceptions of each of its parts that produced these errors. This teaches us about both the relativity and the limits of our perceptions.

While everyone can claim to possess part of the truth, all the protagonists are right about what they have experienced on their own. On the other hand, they are all wrong when claiming to reduce reality to their fragmentary experience. We must therefore be careful not to identify our own point of view, necessarily limited and partial, with global reality. This is all the more important as there is no interest in excluding the other or wasting time making arguments in good faith. On the contrary, there is an interest in cooperating to reconstruct the whole puzzle.

The same is true for the contemporary discourse on zakāt. Everyone talks about it according to his perception of the subject without trying to link the knowledge of the parts to that of the whole. As Blaise Pascal (1844, 2: 72) said: "I think that it is impossible to know the parts without knowing the whole, nor to know the whole without knowing the particular parts".

It should be noted that while Euclid had assumed that "the whole is greater than the part", Aristotle argued that there may be a possibility whereby "the part can be equal to the whole". This led to the hypothesis of an inscription of the whole in each of its parts (Godin, 2000: 182). Such idea is further developed by the hologram principle, according to which not only is the part in the whole but that the whole is inscribed in a certain way in the part (Morin, 2008: 78). In other words, the study of the parts makes it possible to deepen that of the whole and vice-versa, through a constant back and forth, as illustrated in figure 1 .

Figure 1. Back and forth between the parts and the whole

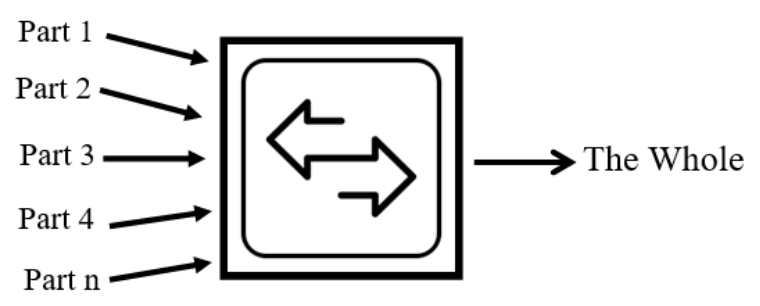

Source: Developed by the author

\section{THE ZAKAT BETWEEN GENERAL AND SPECIFIC MEANING}

The link between zakat and sadaqah allows to grasp more concretely the scope of the study on the relationship between the whole and the parts, and its interest in terms of conceptual analysis, in a perspective of contextualization of knowledge, and awareness of the whole of the system of which it is part.

The concept of zakat is part of the generic concept of sadaqah, which 
is divided into two specific concepts: sadaqah wajjibah (obligatory alms) and sadaqah mustahabah (recommended alms) or which is performed voluntarily (al-Asfahānī, 2002: 380), as illustrated in Figure 2.

Figure 2. The relationship between zakat and sadaqah.

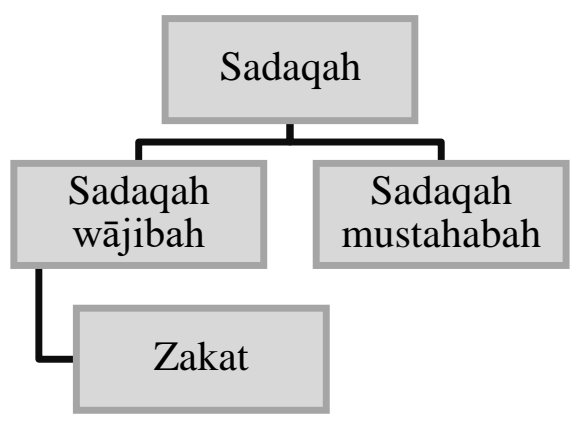

Source: Developed by the author

Zakāt is divided into two concepts: zakāt al-māl (that concerns goods or tangible assets) and zakāt alfitr (intended to purify everything that may have tainted the fasting of the month of Ramadhan) as shown in figure 3.

Figure 3. The types of zakat

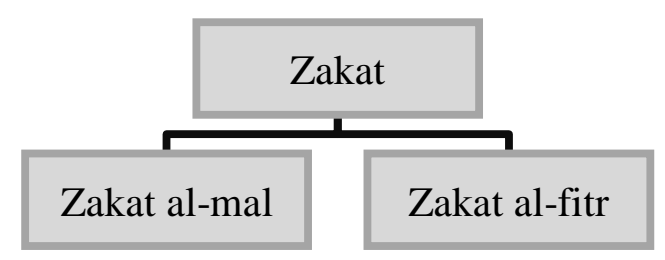

Source: Developed by the author

The sadaqah mustahabah (recommended sadaqah), as illustrated in Figure 4, is divided into two major concepts: sadaqah ma'nawiyah (moral or immaterial almsgiving), sadaqah mādiyah (material almsgiving).

Figure 4. The types of recommended sadaqah

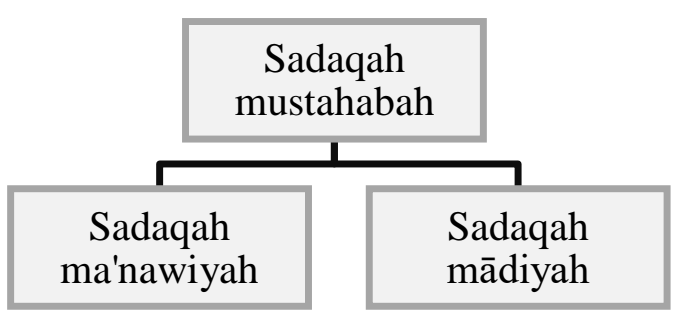

Source: Developed by the author

Almsgiving is not limited to the tangible, material, physical, or accounting aspects. It encompasses an intangible, immaterial, and moral dimension which cannot be quantified in monetary terms. The most important things in life, those that are still there in spite of fluctuations, escape the quantification that attributes a quantum to the measurable phenomenon.

This is confirmed by economic anthropology which has shown that the exchange and giving of gifts is a trait that has always existed at the heart of human societies. It is a natural approach of the relationships between human beings, and is the source behind the creation of social links (Mauss, [1925]2012: 240), their maintenance and their regeneration (Caillé, 1998: 75).

\section{THE NEED TO APPROACH ZAKAT AS A PLURIDIMENSIONAL CONCEPT}

This anthropological interpretation demonstrates the limits of the tendency to reduce zakat to purely material or even monetary considerations. Such considerations, which at first sight seem updated on the progress of research, make difficult to deepen the understanding of the phenomenon and capture its secret melody. Hence the need to approach zakāt as a pluridimensional concept. 
A concept can have many dimensions depending on the angle of view (Depecker, 2003: 85-86). An analysis of the dimensions of a concept makes possible to delimit the relations that it maintains with other concepts, near or far, and to better structure the knowledge, representations, and perceptions towards it.

The concept of zakāt is pluridimensional in that it can be related to many aspects of life. It concerns both jurisprudence (fiqh) (Abu-Saud, 1986) and the contemporary issues that derive from it (nawāzil) (al-Ghafili, 2009), as well as history (Bashear, 1994), anthropology (Abubakar, 2013), sociology (Singer, 2008), economics and finance, all of which gave rise to an immense literature.

These perspectives should be approached as parts, (i.e., elements of a whole), and considered in their relationship with this whole with regard to the risks of underlying cognitive biases, in a permanent back and forth, which scrutinizes the senses without succumbing to the facility of the dominant discourse.

This amounts to linking the pieces of knowledge and restoring them, both in their context and in the whole of which they are part, and to refine the concept of zakāt, tracing its outlines in the light of the challenges, beyond the specific considerations to this or that discipline.

Thus, each perception of zakāt is relative to the other; it can only be defined intrinsically. But taken separately without awareness of the advantages and limits, to the extent that each perception risks draining the concept of its substance.

Hence, the need for a typology that attributes to each party a coefficient that gives it a certain weight, which is far from being obvious, considering the compartmentalization of disciplines that makes impossible to grasp what is woven together, i.e., the complexity of the phenomenon which cannot ignore the uncertainties and insufficiencies faced by the knowledge acquired in a cumulative way.

\section{FINANCIALIZATION OF ZAKĀT AS A MODE OF FINANCING}

The financialization of zakāt, i.e., its perception, above all and despite everything, as a financing tool, illustrates the trap of the compartmentalization of knowledge that prevents the concept from being approached in a contextualized and global manner.

This exercise promises to be difficult as long as the limits of modern science and the ills with which it suffers are not taken into serious consideration, in this case, unilateralism (taking a part for the whole), reductionism (blind to the qualities of the whole), holism (blind to the relations of parties to the whole) (Morin, 2014).

The role of zakāt in financial inclusion, the investments financed by the zakāt fund, and the bank of zakāt are all innovations, resulting from financial engineering, which testifies that the financialization of zakât is underway. Is not the conceptualization of zakāt more and more centered on finance, by depreciating the importance of nonmonetary assets and their social significance, in locally integrated short circuits?!

The financialization of zakāt manifests itself, concretely in everyday life, by the increasingly palpable power of the financial actors over the zakāt collection flows. At this pace, in the future, it will not be only limited to financial services firms, in particular, Islamic banks, or financial holdings; it will probably extend to institutional 
investors, as well as rating agencies that will influence, sooner or later, the value of zakāt assets circulating in the market.

Thus, financialization is a process that will affect the mode of regulation of the collection of zakāt (what are the institutions that structure the relations resulting from them?), and the fructification logic of the associated assets (how they reproduce?).

Until recently, the development of zakāt collection was based on the expansion of agriculture, crafts, commerce and industry, i.e., on the sources of livelihoods recounted in classical and contemporary writings that refer to the fundamentals of kasb or ma'āsh modes (al-Shibān̄̄, 1980: 63; alMawardī, 1999, 15: 153; al-Muzajid, 2007, 1: 447; al-Qazwīn̄i, 2015, 13: 157; al-Dulajī, 1999: 57; al-Kattān̄̄, 2016, 2: 11). The reinvested asset was allocated to investments in these vital sectors of human societies where ecosystem diversity was the rule.

Under the era of financialism (Champaud, 2011), it is a completely different logic that looms on the horizon without awareness of the risks involved. Assets no longer have to go through these sectors to grow. They must circulate, exclusively, in the form of financial assets, whose mere circulation induces creation of new capital.

Short-term investing becomes the priority and the value of an asset is based on speculation that takes advantage of price differentials. However, the risk attached to this type of asset is far greater than that of investments in traditional sectors, since the value of an asset depends on the confidence in it and its variation is fueled by rumors, by nature, very volatile.
The risks incurred under the effect of the financialist approach have the merit of opening the reflection for other perspectives, especially that relating to economic anthropology.

\section{ANTHROPOLOGY OF ZAKĀT AS A VECTOR OF SOCIAL LINK}

The anthropology of zakāt, neglected so far, is a promising prospect to deepen the understanding of the concept, and better grasp its interest, by linking it to the generic concept of sadaqah, which is characterized by giving a smile, a good or a service to others, and is distinguished from the sale, in that it is without valuable consideration, knowing that there are things that are given, things that are sold, and things that must be neither sold nor given (Godelier, 2016: 73).

However, it is important to resist the temptation, inherited from Marcel Mauss ([1925]2012: 68), where the giving or exchange of gifts strives to cover notions that arise from sales. It becomes an all-encompassing concept, which corresponds to exchange in general: merchant and non-merchant. The study of giving should not be dependent on a recurring conflict between economics and anthropology.

These two disciplines, equally important, compete for a common object-very successful in many respects: the study of the circulation of wealth, closely linked to economics (Chagny et al., 2015: 100). The study of gift, or of sadaqah in the Arab-Muslim tradition, must not be undertaken, at the same time, with "a double fascination for economy and for anthropology, i.e., a double contradiction" (MayadeClaustre, 2002: 233-235), masked by a modus vivendi which consists of an implicit sharing of tasks: to the 
anthropology returns the study of archaic and primitive societies; to the economy that of modern and contemporary societies.

Compared to the financialist approach, anthropology has the merit of pointing out that the link is more important than the good. As rightly pointed out by Alain Caillé (2005: 240): "Our narrow definition of gift shows that goods and services are also sometimes worth predominantly, on the basis of their ability to create and reproduce social relationships. So they do not just have a use value and an exchange value, but also a link value. In the gift thus characterized, the fundamental fact is that the link is more important than the good".

Such developments in research deserves more reflection to further deepen the understanding of the concept of zakāt, insofar as it is not only about giving goods to the poor and financing their needs; but it creates social links while enabling the living conditions of the needy. The social link is not less important than the given good, in a long-term perspective anchored locally, favoring the minimization of risks and the maximization of opportunities.

Thus, the concept of zakāt cannot be studied in depth without a thought that contextualizes, connects and globalizes everything that its existence implies for the actors who do not perceive the object in the same way. The articulation of ideas and information and their organization appears to be essential.

\section{THE NEED TO DECONSTRUCT THE DISCOURSE ON ZAKAT}

Faced with this phase difference between signifier and signified, the transfer of a mode of thought on zakāt from one discipline to another seems problematic.

Except to risk a misinterpretation, no discipline can become an instrument that serves as a conceptual reference for others. Hence, the need to analyze the discourses on zakāt in order to identify the meaning of statements and their presuppositions that are not always within the reach of those who hold such or such rhetoric.

For example, the discourse that identifies zakât with a purifying social tax places a special emphasis on the role of the state in the organization of the economy. Whoever assimilates zakāt to a mode of financing gives a predominant role to the individual entrepreneurial initiative. The discourse that emphasizes the role of zakāt in pious or charitable usefulness emphasizes the role of the part of an economy or society comprising nongovernmental and non-profit-making organizations.

From this angle, zakāt is perceived respectively as the constituent of the first, second and third sector. The first sector is the public sector, followed by the private sector, and the third sector, which is defined by the inadequacies of the state and the market (Etzioni, 1973: 314), as illustrated in Figure 5.

Figure 5. The zakat as constituent of the first, second and third sector

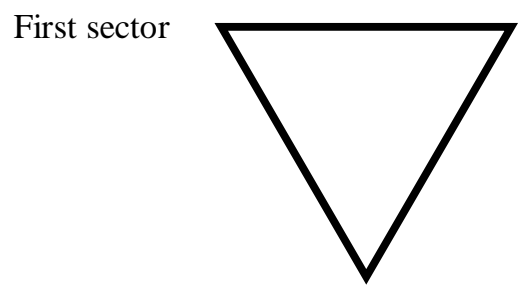

Third sector
Source: Developed by the author 
It should be noted that the reference to zakāt took place in the Mekkan period as stipulated in many verses of the Quran $(23: 4 ; 27: 1-3 ; 31: 3-4 ; 41$ : 6-7), before the creation of the state and the market after the Prophet's migration to Medina. Figure 6 illustrates this historical reality, where zakāt appears somewhat like the first sector, which has not yet been highlighted in the economic literature. This confirms the result of a recent study showing that the waqf belongs to the first sector rather than the third sector (Belabes, 2017). In this, zakāt and waqf fundamentally form the first sector.

Figure 6. Zakat as the first sector

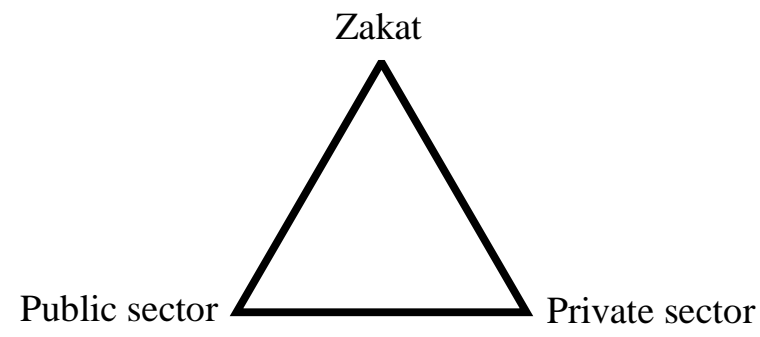

Source: Developed by the author

A historical investigation is of paramount importance. It involves, in more depth, a reflection on the semantic content. The Koranic exegesis stipulates several hypotheses, the most significant of which is that the zakāt of assets was instituted in Makkah. The sampling thresholds and the specific proportions were instituted in year two of the Prophet's migration to Medina, as noted by Ibn Kathīr (2000, 10: 108).

As such, the classical classifications of zakāt, relating to expenditures and public revenues (Ibn 'Abd al-Salām, 2007, 1: 476-484, Ibn Zinjawīh, 1986, 3: 759-761), deserve to be enriched. Contemporary studies, that consider zakāt as an essential component of the social safety net (Toor and Abu Nasar, 2004, Ahmad et al., 2017), or as a pillar of the social and solidarity economy (Sigillò and De Facci, 2018), need to be put into perspective despite the interest they arouse and the reflection they spread.

\section{CONCLUSION}

The main results of the study are as follows:

i. To consider the concept of zakāt as a pluridimensional object under pain of emptying it of its substance and compromising the realization of its objectives.

ii. Addressing the different dimensions of the concept beyond purely economic and financial considerations that have shown their limit in more ways than one.

iii. Deepening each dimension so that the parts enrich the comprehension of the whole and vice versa, through a constant back and forth.

iv. Avoiding the possibility of one dimension, regardless of the interest aroused, taking precedence over others and thus impoverishing the comprehension of the whole.

In this way, the concept of zakāt touches both practical, theoretical and methodological aspects. This undermines the conceptualization of zakāt as a vector of economic development or the competitiveness of social entrepreneurship, the respective indicators, the fact of considering zakāt, purely and simply, as a component of the social safety net, or the social and solidarity economy, insofar as the concept involves both the role of the 
State, the market, and actors that do not fall under either of them.

In view of these results, the study recommends the following:

i. To deepen the varied dimensions of the concept beyond the purely economic and financial considerations that take on the lion's share.

ii. Develop a definition of the concept that is better able to meet the needs of this process in a renewed way.

iii. Explore the impact of this pluridimensional approach on economic analysis.

iv. Especially that which stipulates that it is necessary beforehand to produce wealth before distributing it. This raises a fundamental question: Does the social dimension boil down to a redistribution of wealth or does it encompass other purposes that are nonetheless important?

\section{ACKNOWLEDGEMENT}

This study is funded by the Chair of Dr. Abdulhadi H. Taher for Studies of Fiqh and Accounting of Zakāt, Faculty of Economics and Administration, King Abdulaziz University, Jeddah, Saudi Arabia.

\section{REFERENCES}

Abubakar, Dauda (2013). The Giving and Receiving of Zakāt: Anthropological Analysis of Relationship between the 'Wealthy' and 'Needy' Citizens in Jos, Nigeria, International Journal of Humanities and Social Science, Vol. 3 No. 9; May, pp. 289-296.

Abu-Saud, Mahmoud (1986). About the Fiqh of. Zakāh, Cincinnati: Zakah and Research Foundation.
Ahmad, Mahtab, Sophia F. Dziegielewski, Ibrar Tariq \& Abbirah Zulfiqar Bhutta (2017). Zakat as a Social Safety Net: Assessing its Perception in a LessDeveloped Rural District in Pakistan, Journal of Social Service Research, Vol. 43, Issue 3, pp. 369-380.

Al-Ghafili, Abdullah (2009). Nawāzil al-Zakāt, Riyadh: Bank al-Bilad.

Al-Kattān̄̄, 'Abd al-Ḥay (2016). AlTarātīb al-Idāriyah, Beirut: Sharikat Dar al-Arqam.

Al-Mawardī, 'Alī (1999). al-Hāwì alKabīr fì Fiqh Madhab al-Imām alShäfi' $\bar{\imath}$, Beirut: Dar al-Kotob al'Ilmiyah.

al-Muzajid, Safiyuddin (2007). Kitāa al-'Ubāb al-Muhīt bi-Mu'zam Nuṣūṣ al-Shāfi't wa-al-Așhāab, Beirut: Dar Al Kotob Al Ilmiyah.

Al-Qazwīnī, 'Abdul Karīm (2015). Al'Azīz Sharh al-Wazìj, Beirut: Dar al-Kotob al-'Ilmiyah.

al-Rāghib al-Asbahānī (2002). Mufradāt fi Gharīb al-Qur'ān, Damascus Beirut: Dar al-Qalam - Dar alShamiyah.

Bashear, Suliman (1994). On the Origins and Development of the Meaning of Zakāt in Early Islam, Arabica, pp. 84-113.

Belabes, Abderrazak (2017). Is the Waqf a Part of the Third Sector?, The Journal of Awqaf, No. 33, November, pp. 12-35.

Caillé, Alain (2005). Don, intérêt et désintéressement, Bourdieu, Mauss, Platon et quelques autres, Paris: La Découverte-Mauss.

Caillé, Alain (1998). Don et association, Revue du MAUSS, No. 11, pp. 7583.

Chagny, Charlie, Dufraisse, Sylvain, Martin, Marguerite, Pouly, Charlotte et Quillien, Louise (2015). Penser les circulations 
économiques, Hypothèses, 2015/1, 18, pp. 95-104.

Champaud, Claude (2011). Manifeste pour la doctrine de l'entreprise Sortir de la crise du financialisme, Bruxelles: Larcier.

Etzioni, Amitai (1973). The Third Sector and Domestic Missions, Public Administration Review, Vol. 33, No. 4 (Jul. - Aug.), pp. 314-323.

Godelier, Maurcie (2016). In Today's World, Anthropology is More Important than Ever, Revista de Antropología Iberoamericana, Vol. 11, Issue 1, January-April, pp 59-76.

Ibn Kathīr, 'Imād ad-Dīn (2000). Tafsīr al-Qur'ān al-'Azìm, al-Jizah: Muasassat Qurtubah - Maktabat Awlad al-Sheikh li-al-Turath.

Mauss, Marcel ([1925]2012). Essai sur le don, Paris: Presses Universitaires de France.

Mayade-Claustre, Julie (2002). Le don: Que faire de l'anthropologie ?, Hypothèses, 2002/1 (5), pp. 229237

Morin, Edgar (2008). La pensée complexe: Antidote pour les pensées uniques, entretien realisé par Nelson Vallejo-Gomez, Synergies Roumanie, ${ }^{\circ} 3$, pp. 7790.

Morin, Edgar (2014). L'avenir: probable et improbable, Conférences Penser Global, Fondation maison des sciences de l'homme, Université Paris 1 PanthéonSorbonne, 7 Mars, http://www.fmsh.fr/fr/ recherche/26795

Pascal, Blaise (1844). Pensées, fragments et lettres de Blaise Pascal, Volume Second, Paris: Andrieux Editeur.
Sigillò, Ester et De Facci, Damiano (2018). L'économie sociale et solidaire: une nouvelle économie morale pour la Tunisie ?, L'Année du Maghreb, 18, pp. 51-68.

Singer, Amy (2008). Charity in Islamic Societies, New York: Cambridge University Press. 
